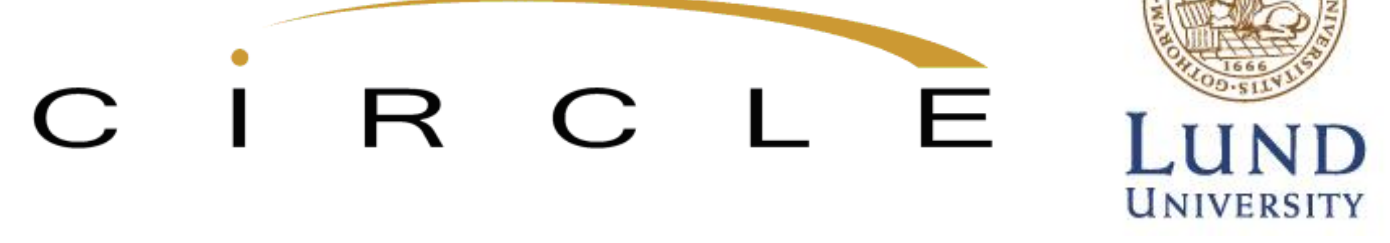

Paper no. 2013/37

\title{
Physical Planning in Place-Making through Design and Image Building
}

Ana Mafalda Madureira (Ana Mafalda.Madureira@circle.lu.se $)$ CIRCLE, Lund University, and Blekinge Tekniska Högskola Sweden

This is a preprint of an article whose final and definitive form will be published in the Journal of Housing and the Built Environment (c) [2013] [copyright Springer]; available online at:

http://link.springer.com/article/10.1007\%2Fs10901-013-9381-

2/fulltext.html

Citations to and quotations from this work should reference that publication. If you use this work, please check that the published form contains precisely the material to which you intend to refer.

This version: December 2013

Centre for Innovation, Research and Competence in the Learning Economy (CIRCLE)

Lund University

P.O. Box 117, Sölvegatan 16, S-221 00 Lund, SWEDEN

http://www.circle.lu.se/publications 
WP 2013/37

\section{Physical Planning in Place-Making through Design and Image Building}

Ana Mafalda Madureira

\section{ABSTRACT}

This paper discusses how physical planning works with place-making through urban design to support image creation in a municipality that aims to create a new image for its city. Two large-scale urban development projects in Sweden are analysed. The analysis focuses on official plans and documentation, and expert interviews. It distinguishes how place-making by physical planning happens through aestheticisation, the design of physical environments for specific groups of inhabitants, and by granting visual and symbolic coherence to an area aligned with the new image for the city. The construction of this image is kick-started by a flagship development, but requires that subsequent projects support complementing urban visions, so as to grant coherence to the perceptions of the new image. In the process, heterogeneity, variation and conflict are tamed and urbanity is framed for "creative classes". The paper thus highlights potential dilemmas that place-making might create for the practice of physical planning in urban development, and contributes to the discussions on the transformation of public sector urban planning in contexts of urban entrepreneurialism..

JEL Code: $\mathrm{O} 21$

Keywords: Physical planning; Place-making; Urban entrepreneurialism

Disclaimer: All the opinions expressed in this paper are the responsibility of the individual author or authors and do not necessarily represent the views of other CIRCLE researchers. 


\title{
Physical Planning in Place-Making through Design and Image Building ${ }^{1}$
}

\author{
ANA MAFALDA MADUREIRA
}

\begin{abstract}
This paper discusses how physical planning works with place-making through urban design to support image creation in a municipality that aims to create a new image for its city. Two largescale urban development projects in Sweden are analysed. The analysis focuses on official plans and documentation, and expert interviews. It distinguishes how place-making by physical planning happens through aestheticisation, the design of physical environments for specific groups of inhabitants, and by granting visual and symbolic coherence to an area aligned with the new image for the city. The construction of this image is kick-started by a flagship development, but requires that subsequent projects support complementing urban visions, so as to grant coherence to the perceptions of the new image. In the process, heterogeneity, variation and conflict are tamed and urbanity is framed for "creative classes". The paper thus highlights potential dilemmas that place-making might create for the practice of physical planning in urban development, and contributes to the discussions on the transformation of public sector urban planning in contexts of urban entrepreneurialism.
\end{abstract}

Key Words: Physical planning; Place-making; Urban entrepreneurialism

\section{Introduction}

Malmö is a Swedish municipality that has been consciously constructing a new image for the city, "From Industrial City towards Knowledge City" (Planering i Malmö, 2010:2, p. 30), and supporting this new image through discourses and urban development (Dannestam, 2009; Möllerström, 2011; Holgersen, 2012). There are two competing images of Malmö: one associated with industrialisation, and another that is emerging now and is connected with the socioeconomic restructuring of the city. The urban fabric reflected the symbols of the industrial era and is now being transformed: the shipyard Kockums dominating the city during industrialisation, and the Turning Torso, the new university-college and the Öresund Bridge reflecting a new Malmö for the 21st century (Stigendal, 2004). The new image is being targeted towards the Knowledge Economy, with sustainability and urbanity as associated discourses. The

\footnotetext{
${ }^{1}$ Published at the journal of Housing and the Built Environment - DOI: 10.1007/s10901-013-9381-2
} 
need to strengthen a specific profile for the city is linked with growing intercity competition to attract inward investment and companies.

The development of Malmö illustrates a trend that has been well documented in other cities, especially those hit by industrial decline (Hubbard, 1996; Hamnett and Whitelegg, 2007; Russo, 2008). The strategies pursued in the transformation of the city's image often place an emphasis on changes in the urban form and in the perception of the city by inhabitants and visitors. Additionally these strategies focus on the physical environment as the main factor in revitalising the economic and social spheres (Hubbard, 1996). Gospodini (2006) refers to a change of paradigm. Large-scale urban development projects (LSUDPs) and the investment in major architectural landmarks are seen as a way to promote economic development, not as a reflection of a city that is enjoying a good economic momentum and engaging in urban development. Urban design is used to refashion and better sell the image of the city to investors, and it can be seen in the branding of a city (Ashworth and Kavaratzis, 2009; Gold and Ward, 1994), in the promotion of distinct cultural assets and leisure areas, or by developing businesses and $R \& D$ districts within the city (Gospodini, 2006).

Strategies of place-making tend to focus on the creation of physical environments that will be associated with what are seen as the characteristics of new economic activities to be attracted: innovation, creativity and knowledge (Hubbard, 1996; Bradley et al., 2002; Landry, 2000; Florida, 2004; Barnes et al., 2006; Gospodini, 2006; Hutton, 2006). The city's authorities, for example in traditional manufacturing towns, are confronted with the existence of built environments that do not reflect the ambitious socioeconomic goals simply because the factory is no longer a central element in the socioeconomic life. Additionally, there is growing literature and research that argues for the promotion of cultural and leisure activities and the provision of consumption amenities in both quantity and quality (Landry, 2000; Florida, 2004; Hospers and Pen, 2008; Shimomura and Matsumoto, 2010). Their message for policymakers is to focus policies on these fields so that the city can be more competitive to attract the people and activities supporting the Knowledge Economy.

This is an urban policy approach that often begins with highly-publicised and speculative flagship developments - meaning a large-scale urban renewal project intended to be a catalyst for local economic development, a break against inner-city decline trends - that create a symbol or a new image for the city and attract investments (Bianchini et al., 1992). However, for the new image of the city to be consolidated, urban development needs to convey a similar vision also in its lesspublicised projects. This implies a mainstreaming of the values and goals conveyed by flagship developments.

The aim of this paper is to discuss how physical planning works with place-making through urban design to support image creation in a municipality that aims to create a new image for this city.

In Sweden, the bulk of the planning tasks are found at the local level. Urban planning (Fysisk Planering) is a formal responsibility of the local authorities and, in principle, the local authority has a planning monopoly. In this paper the concept of physical planning will be used to indicate municipal urban planning and the local planning department. 
The analysis is set against the background of urban entrepreneurialism, in which city governments focus on developing strategies to promote local economic development (Hall and Hubbard, 1998; Harvey, 1989; Wood, 1998). Urban renewal projects are geared towards the creation of places that will attract and cater to the needs that knowledge-based activities and the people working in them have regarding the built environment. There is a high value on the characteristics of a place that can contribute to the competitive advantage of one location over the other (Amin and Thrift, 1995). This implies that physical planning holds a key position in the transformation of a city's built environment within local economic promotion strategies. Physical planning is expected to anticipate the needs for soft aspects such as quality of life and the ensemble of specific services and supporting industries for specific groups of users and uses.

This paper contributes to the literature on the transformation of public sector urban planning in contexts of urban entrepreneurialism in urban policy (Harvey, 1989; McGuirk and MacLaran, 2001; Tasan-Kok and Baeten, 2012). It also highlights a dilemma for planning practitioners in Sweden: how to preserve diversity and plan for a city's current inhabitants, following the traditions of planning to deliver State welfare to all (Appelbaum, 1985; Blucher 2006; Strömgren, 2007), and simultaneously embrace physical planning to promote knowledge-based activities, attract the "creative classes" and promote economic growth.

\subsection{Research Design}

The paper uses a case-study approach (Yin, 2003). It focuses on the urban design elements, functions and users intended for a neighbourhood, and on the image that physical planners create for the neighbourhood in connection to the new image for the city. These aspects were first analysed through comprehensive and detailed plans, on-site visits and official documentation and later complemented by expert interviews. The interviewees were mainly planners directly involved with the two projects, as well as other planners at the municipality, who discussed the mainstreaming of values and practices from the flagship project to subsequent projects; the mayor and an information officer complemented the discussion about the new image for the city.

The cases were selected because they illustrate two distinct moments in the municipal efforts to create a new image for Malmö. However, there are clear parallels in how physical planning uses urban design to convey the new image and for whom these neighbourhoods are intended (figure 1).

Bo01 was the site of a housing exhibition meant to promote Malmö as a sustainable City of Tomorrow for new investments, particularly in knowledge-intensive industries, and to attract back to the city the wealthy taxpayers who left Malmö during its manufacturing heyday. Bo means "to inhabit" in Swedish, and 2001 was the year of the exhibition. It is an example of a flagship project, deliberately designed to show the inhabitants of Malmö and outsiders that there was a new city being born and to unveil a new era for Malmö.

The Norra Sorgenfri LSUDP focuses on the promotion of social and spatial integration within Malmö, aiming to extend the investment, land-value and attractiveness of the city centre towards the less affluent eastern parts. The formalised intentions for the intervention are social and 
economic and less concerned with a rehabilitation of the urban form per se. But this rehabilitation is understood as enabling the development of a new image for the neighbourhood to contribute to the new image of Malmö and to promote improved economic activity and quality of life (Malmö Stad, 2005). Together, these two projects contribute to the development of the image of Malmö as a Knowledge City, one as an initiator of a change of image, the other consolidating that new image.

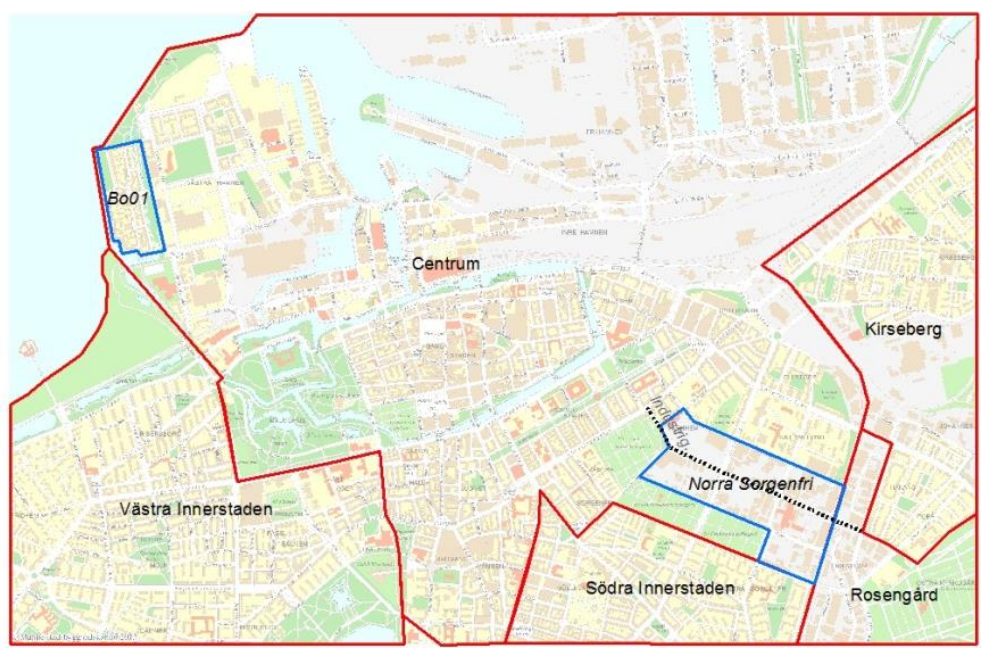

Figure 1- Location of Bo01 and Norra Sorgenfri in relation to city centre and surrounding city districts. 2011

Source: malmo.se/karta. (C) Malmö stadsbyggnadskontor. Cartographer: Maria Rodriguez-Rabadan.

\section{2.}

\section{Physical planning for place-making}

Physical planning is participating in urban development projects where two spheres are manipulated in favour of the creation of a new image. The first is the tangible sphere - the built environment, focusing especially on public spaces (streets, sidewalks, parks, squares) and quasipublic/ commercial spaces (facades of buildings, street-level commerce, shopping streets). Urban design contributes to the image of value associated with a potential investment site (Carmona et al., 2002; Harvey, 2006). Madanipour (2006) discusses how urban design's rising importance within urban policy and planning can be linked back to its potential contribution to making the city more competitive against other cities by being involved in place-branding strategies and by shaping the urban landscape to resemble the intended image to be created. The sense of distinction that urban design can grant to a city is visible in the heritage of Gaudi in Barcelona or Haussmann in Paris. However, recent literature has criticised the homogenisation of architectural and urban design styles and the creation of serialised landscapes of consumption (Lovering and Sartorio, 2007; Ben-Joseph, 2009). In the quest to develop an image of innovation, creativity and knowledge economy for the city, the builders of physical environments (policymakers, planners, designers, architects, developers) have fallen into the reproduction of what Gospodini (2006) calls the "landscapes of the post-industrial city".

Physical planning also works with an intangible sphere that comprises the intended function that neighbourhood will have for the city, how it contributes to the new image, and who the intended 
"public" of the neighbourhood is. This is supported through marketing and place-branding, which are central to the development of these neighbourhoods within a specific cultural and commercial symbology (Zukin, 1995). Critics have pointed out that urban policy strategies to attract the "creative classes" work parallel to the development of gentrification processes and a progressive neoliberalisation of development agendas, pushed forward by loose concepts such as intercity competition (Smith, 2002; Peck, 2005; MacLeod and Johnstone, 2012). Marcuse (2005) argued against conflating the needs and demands of a heterogeneous group of urban dwellers into a single need and demand, highlighting the perverse effects that arise when the needs of "creative classes", capital or intercity competition are taken to represent the needs of all of a city's inhabitants and companies. Nevertheless, the reorientation of urban policy towards proactive strategies to promote a city for knowledge-based activities and the people working in these activities, justified within a discourse of intercity competition, is carried out by local governments (Hubbard, 1995; Jensen-Butler et al., 1997; Paddison, 1993; Rousseau, 2009) and organisations such as the OECD (OECD, 2007).

The manipulation of these spheres by physical planning is visible in the cases I turn to next.

\section{A new image for Malmö}

"In the process of going from an industrial city to a new city, with a new brand, three strategic projects were recognized [by Malmö Stad]. One was the housing project Bo01, the other was Malmö University-College, and the third, concerned the environmental questions and the public spaces" (Interview Larsson)

The Bo01 exhibition was held in Western Harbour, a peninsula that had previously hosted one of the industries that were a symbol for the industrial Malmö, the shipyard Kockums. In 1989, when the production of military ships moved out of the city, 27000 people lost their jobs.

The area's potential for the organisers of Bo01 lay in its prime location: proximity to the sea and to the centre (Interviews Blucher; Reepalu). Additionally, in the 1990s the area had abandoned and empty plots and evoked the idea of a past industrial age. Bo01 signalled the beginning of a series of urban renewal projects intended to promote Malmö as a Knowledge City. This was a project meant to promote the city to outsiders (Interviews Blucher; Reepalu; Johansson), and continues to be used by the municipality as an example of its efforts to develop a new image for Malmö.

The goal was that Bo01 would combine living, education and work functions, world-class architecture, and leading-edge technologies in sustainable building and design, and provide a marketing area for ecological and sustainable solutions for cities. Simultaneously it would show visitors and the world the image of a new Malmö that was leaving behind its past of industrial decline and embracing the opportunities offered by new technologies, trends and ideologies. Because the exhibition focused on housing, Bo01 is essentially a residential and leisure area, but the wider district has since developed into a mixed-use area.

The industrial district of Norra Sorgenfri is also being transformed into residential, commercial and office areas. The municipality considers the project to be strategic as it aligns with the goal of 
the upcoming comprehensive plan of promoting a sustainable city by building on already urbanised land and promoting mixed-use areas and higher densities (Malmö Stad, 2013).

When the industrial area of Norra Sorgenfri started to develop in the late 1800's, it was located on the outskirts of Malmö. Nowadays, with the expansion of the city, it is centrally located. Originally the area was occupied by different manufacturing companies and used for tram depots. Today there are still some industries, but manufacturing is no longer an important activity. There are many abandoned and underused buildings and plots, a situation unusual to find in such close proximity to a city centre. Additionally, the area was never an important residential or service/ commercial area. As such, the existing buildings and infrastructure area are characteristic of the industrial city that Malmö once was.

The official discourse is built around the potential of this area to develop attractive urban-like characteristics such as higher densities, variation and lively streets, reaping its potential from the close proximity to the more affluent city centre. It could also be understood as an effort to expand the city centre towards the east, with the corresponding increase in land-value also moving eastwards.

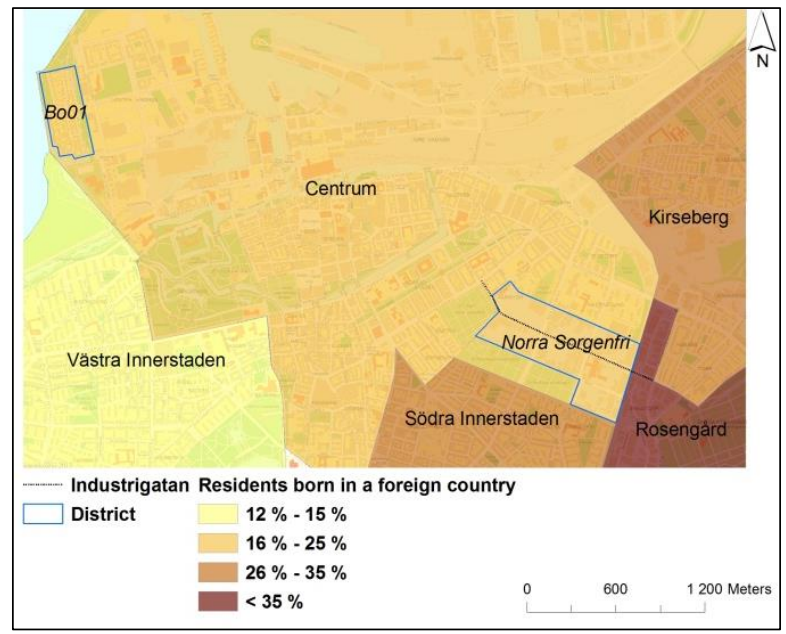

Figure 2a- Percentage of residents born in a foreign country, in relation to total resident population, by city district, 2008

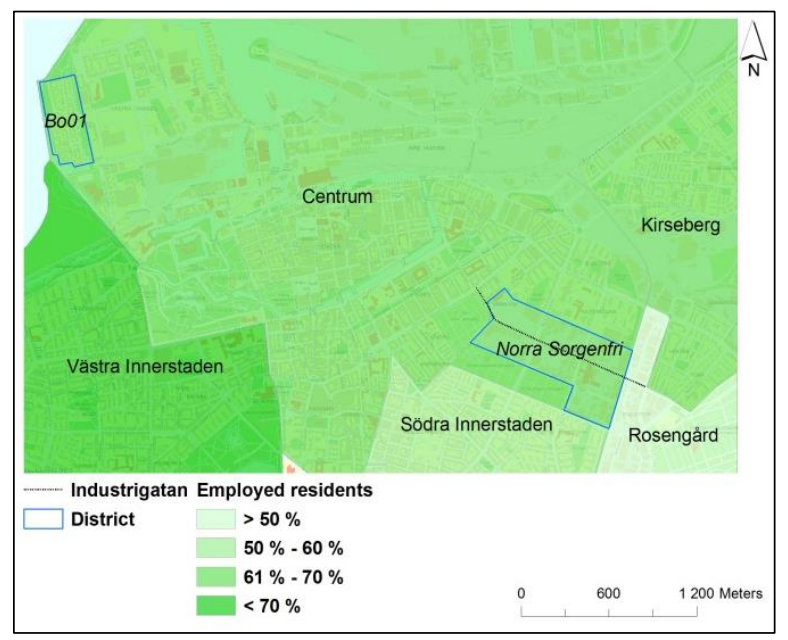

Figure 2c- Percentage of employed residents, in relation to total resident population, by city district, 2008

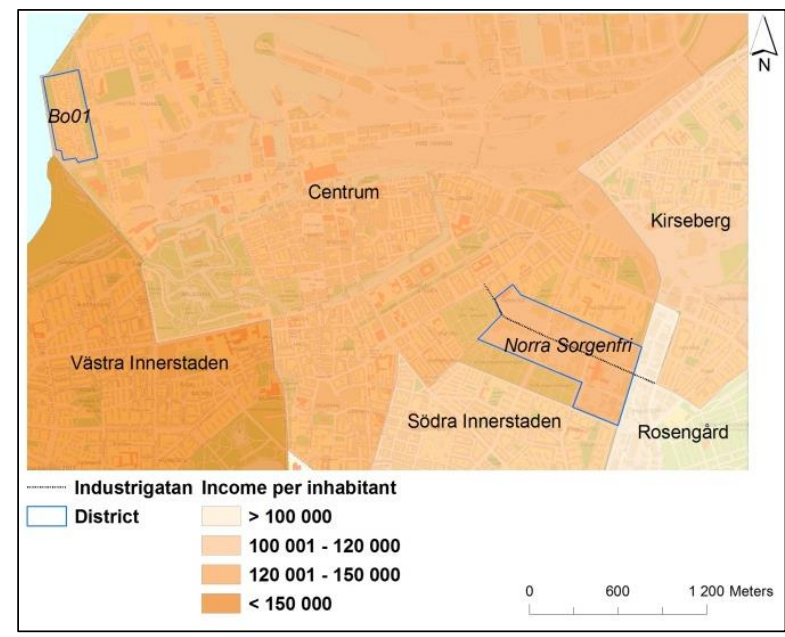

Figure 2b- Income per inhabitant, by city district, 2008

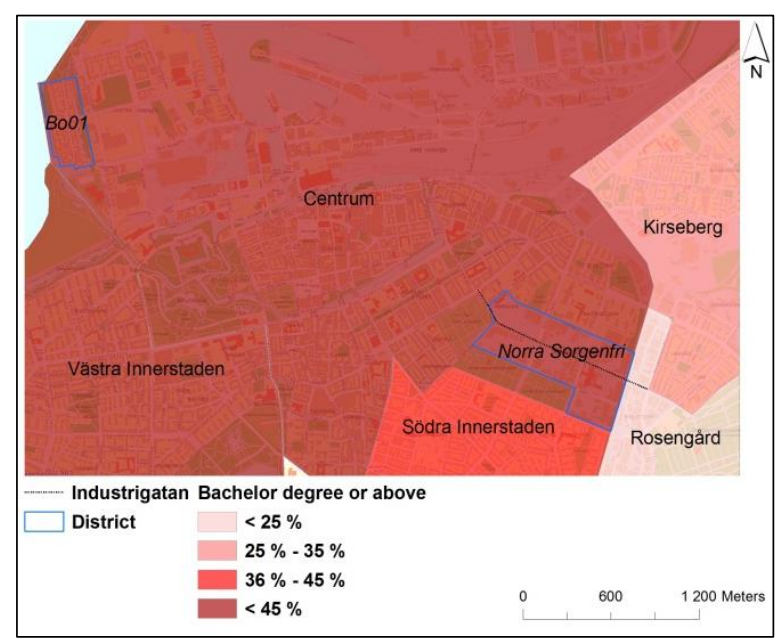

Figure 2d- Percentage of residents with a bachelor degree or above, in relation to total resident population, by city district, 2008 
Source: malmo.se/karta. (C) Malmö stadsbyggnadskontor. Cartographer: Maria Rodriguez-Rabadan.

Malmö is considered to be segregated (Mukhtar-Landgren, 2005; 2008), with a more affluent western part and an inflow of wealthy citizens to the well-off areas of Western Harbour (Malmö Stad, 2012). The eastern parts of Malmö have less affluent populations and a higher concentration of immigrants, the unemployed and lower-income families (Malmö Stad, 2008a; figures $2 \mathrm{a}, 2 \mathrm{~b}, 2 \mathrm{c}$ and $2 \mathrm{~d}$ ). This does not sit well with a municipality that is still dominated by Social Democrats and with a recent history of a working-class city, home to trade union movements (Vall, 2007). Norra Sorgenfri is aimed at addressing this spatial segregation by serving as a transit corridor, meaning that the area is being promoted as a bridge that would bring the two areas together and promote circulation from one area to the other. The inhabitants of the eastern districts would have a more direct connection to the city centre via Industrigatan, one of the main streets through Norra Sorgenfri. The location of housing and services in Norra Sorgenfri would potentially bring people from the rest of Malmö to this area and create jobs. One can also understand Norra Sorgenfri as a municipal effort to expand the gentrification process already taking place in central Malmö (Hedin et al., 2012) that would push the lower-income households further into the eastern peripheries and away from the city centre.

Table 1 provides an overview of the two projects according to their urban design elements and how they contribute to the image of the city.

\begin{tabular}{|c|c|c|c|}
\hline & & Bo01 & Norra Sorgenfri \\
\hline \multirow[t]{4}{*}{$\begin{array}{l}\text { Urban } \\
\text { Form }\end{array}$} & $\begin{array}{lr}\text { Integration } & \text { with } \\
\text { existing } & \text { natural } \\
\text { and } & \text { historical } \\
\text { features } & \end{array}$ & $\begin{array}{l}\text { Uses natural landscape as } \\
\text { attraction factor } \\
\text { No pre-existing built heritage to } \\
\text { re-use } \\
\text { No traces of industrial tradition } \\
\text { in new buildings }\end{array}$ & $\begin{array}{l}\text { Preservation of industrial built } \\
\text { heritage as attraction factor } \\
\text { Industrial architecture style and } \\
\text { materials to be present in new } \\
\text { constructions }\end{array}$ \\
\hline & Street network & $\begin{array}{l}\text { Basic grid network } \\
\text { Two main promenades with } \\
\text { distinct characteristics } \\
\text { Inner streets, green areas and } \\
\text { small squares with semi-private } \\
\text { function }\end{array}$ & $\begin{array}{l}\text { Maintain existing grid network } \\
\text { Creation of secondary network of } \\
\text { streets and green areas for } \\
\text { pedestrians and cyclists }\end{array}$ \\
\hline & $\begin{array}{l}\text { Characteristics of } \\
\text { plots }\end{array}$ & $\begin{array}{l}\text { Small blocks distributed by } \\
\text { many developers/ architects for } \\
\text { greater visual diversity and to } \\
\text { increase accessibility }\end{array}$ & $\begin{array}{l}\text { Small blocks distributed by many } \\
\text { developers/ architects for greater } \\
\text { visual diversity and to increase } \\
\text { accessibility }\end{array}$ \\
\hline & Individualising & Turning Torso; & Industrial architecture; \\
\hline
\end{tabular}




\begin{tabular}{|l|l|l|}
\hline \multicolumn{1}{|c|}{ elements } & Sustainability theme & $\begin{array}{l}\text { Reconversion of bus depot for } \\
\text { cultural activities }\end{array}$ \\
\hline $\begin{array}{l}\text { Intended users of private } \\
\text { spaces }\end{array}$ & Upper-middle classes & Socio-economic and cultural diversity \\
\hline $\begin{array}{l}\text { Intended users of public } \\
\text { spaces }\end{array}$ & Inhabitants of the city, visitors & Inhabitants of the city, visitors \\
\hline Function for the city & $\begin{array}{l}\text { Mixed-used neighbourhood } \\
\text { that provides high-quality } \\
\text { housing areas } \\
\text { Re-use industrial land }\end{array}$ & $\begin{array}{l}\text { Corridor that connects central and } \\
\text { eastern Malmö } \\
\text { Mixed-use development in under- } \\
\text { valued area }\end{array}$ \\
\hline $\begin{array}{l}\text { How project contributes to } \\
\text { city image }\end{array}$ & $\begin{array}{l}\text { Build image of Malmö as } \\
\text { sustainable, innovative and } \\
\text { attractive to live in }\end{array}$ & $\begin{array}{l}\text { Address image of segregation } \\
\text { Create ethnic, tolerant and diverse } \\
\text { environment, aligned with "creative } \\
\text { city" rhetoric }\end{array}$ \\
\hline
\end{tabular}

Table 1- Overview of projects

\subsection{The flagship project - Bo01}

\subsubsection{The tangible sphere}

The plans for the transformation of the area were created around the natural and geographical features of the site instead of existing structures. The sea was used as a central element of the public areas, complemented by the sight of the recently inaugurated Öresund Bridge representing the link to the continent, the connection to Copenhagen and the integration to the wider Öresund region. Along the sea, a promenade area was designed, lined by new buildings in a new contemporary and innovative architectural style

(Figure 3).

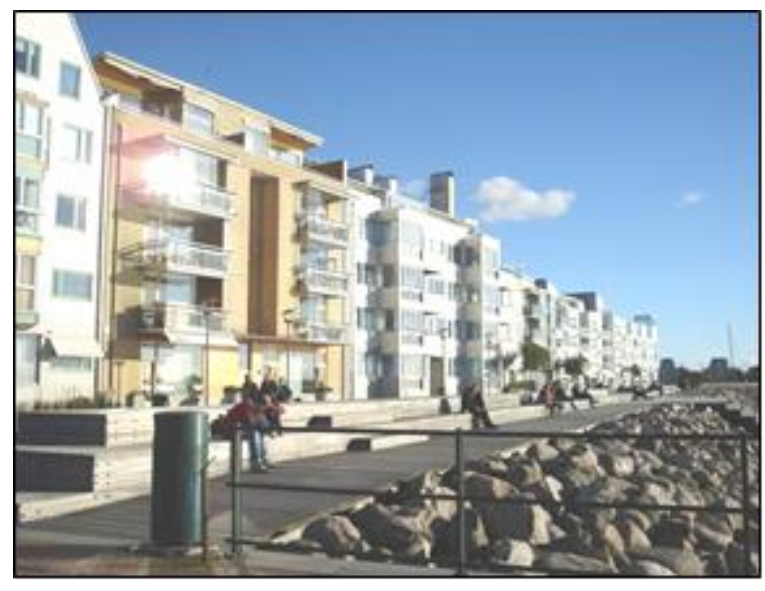

Figure 3- Sundspromenaden

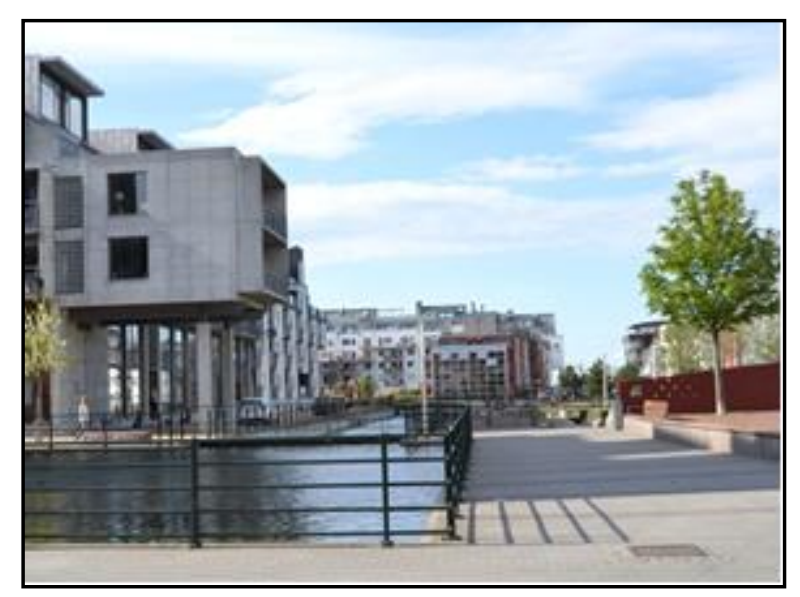

Figure 4- View of Ankarparken

Sundspromenaden and Ankarparken form the basic street network. Sundspromenaden, running parallel to the sea, offers a beach area to the city's dwellers. At the street level, cafés and shops are meant to ensure the liveability of the promenade. Ankarparken is more sheltered and greenery 
is its distinguishing feature. (Figure 4) The inner facades create a network of little squares for private gardens with abundant vegetation (Figure 5).

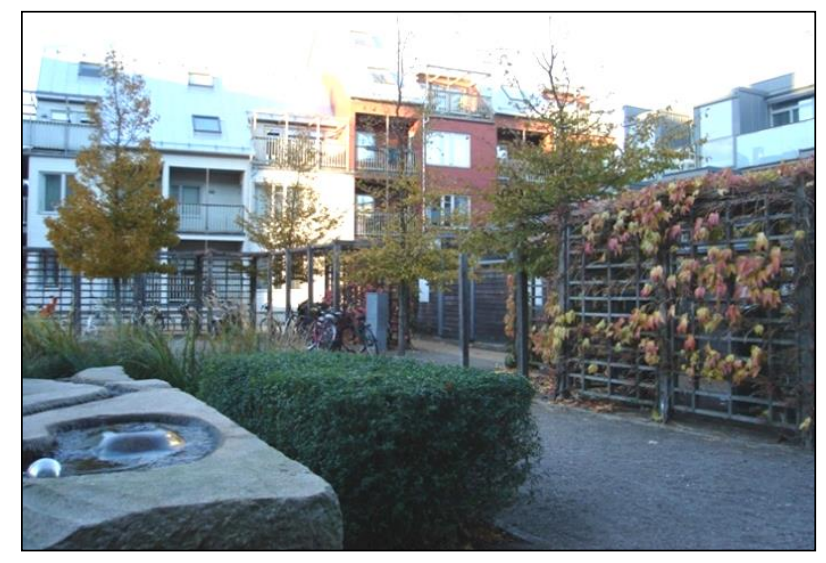

Figure 5- Green areas in the interior of the plots

The urban form taking shape in Bo01 paid compliment to contemporary ideals regarding what a city of (and for) tomorrow should look like, and represented a different approach to urban design from what had been the case in Swedish planning in the last 30 to 40 years (Interview Blucher), when the trend was to build in larger plots, which were allotted to a small number of developers and architects, with the resulting urban form more homogenous and large-scale. The new area did not reflect the history of the district in particular, but rather a mixture of contemporary styles, sizes, and influences. Who might the intended target be except for the new inhabitants that municipal expectations hoped would choose Bo01 and Malmö to settle in?

\subsubsection{The intangible sphere}

This brings us to the intangible sphere. Bo01 was clearly designed for upper-income families. This was the goal of city officials (Interviews Larsson; Reepalu) that wanted to attract back to the city those families that had left Malmö for the suburbs during the industrial times. "[Malmö] at that point, needed to have better housing areas. [Malmö is] in the periphery [of the region], quite dominated by large scale [housing] areas. If we wanted to be attractive for other life styles and other families, we had to create some new, attractive, housing areas" (Interview Larsson). The housing exhibition team wanted a more mixed-income area (Interview Blucher). The municipality ambitions won.

Even though the neighbourhood was intended for high-quality housing for higher-income families, the public spaces were meant to serve the whole city and contribute to Malmö's new image. The apartments and houses were expensive due to the pioneering solutions for environmentally friendly buildings and the high-quality design and aesthetic of the area. However, lessons learned from the Bo01 experience were used in subsequent urban development projects across the city, including trying to add greater diversity of incomes to new housing developments in Western Harbour by negotiating with developers to reserve a percentage of dwellings for rental and agreeing on a maximum price for rents (Interview Andersson).

The emphasis on attracting the upper-middle classes and on creating a city for new inhabitants was criticised by scholars concerned with the segregation effects it produced within the city itself 
(Mukhtar-Landgren, 2005), with the resulting gentrification of Western Harbour and neighbouring areas of Malmö (Hedin et al., 2012), and with the use of Bo01 and Western Harbour in official discourses that promote an image of (positive) change and downplay or omit the socioeconomic polarisation in Malmö (Holgersen, 2012).

The tangible and the intangible were thus working together in the transformation of Bo01 and in creating the catalyst for the change of Malmö's image. It was the start of a new city, and visitors and inhabitants could see it.

\subsection{An extended city centre in Norra Sorgenfri}

\subsubsection{The tangible sphere}

In the reconversion of Norra Sorgenfri, the intention is for existing buildings to be maintained and for new construction to respect the area's original industrial character (Malmö Stad, 2008b), following the recommendations of an evaluation of the value of the buildings and urban morphology commissioned by the municipality. It was argued that the area has an architectural and historical value linked with its industrial history and that this feature should be explored in its reconversion. The buildings vary in style, materials used, era and size, granting diversity to the neighbourhood and flexibility of potential uses (Schlyter, 2006). It might also be seen as an indication that the municipality has made its peace with its past of industrial decline and is now using this past to promote a story of successful recovery.

The municipality defined other broad guidelines for how urban design is to convey the desired inner-city character, namely the orientation of facades towards main streets and the height of buildings. The ground level facing the main streets is to be reserved for shops, cafés and other services (Figure 6). A wide range of developers and builders is expected to ensure a great diversity of housing and commercial solutions to invite different forms of living, people from different ages and backgrounds, and different economic and leisure activities (Interview Kronwall and Lundqvist).

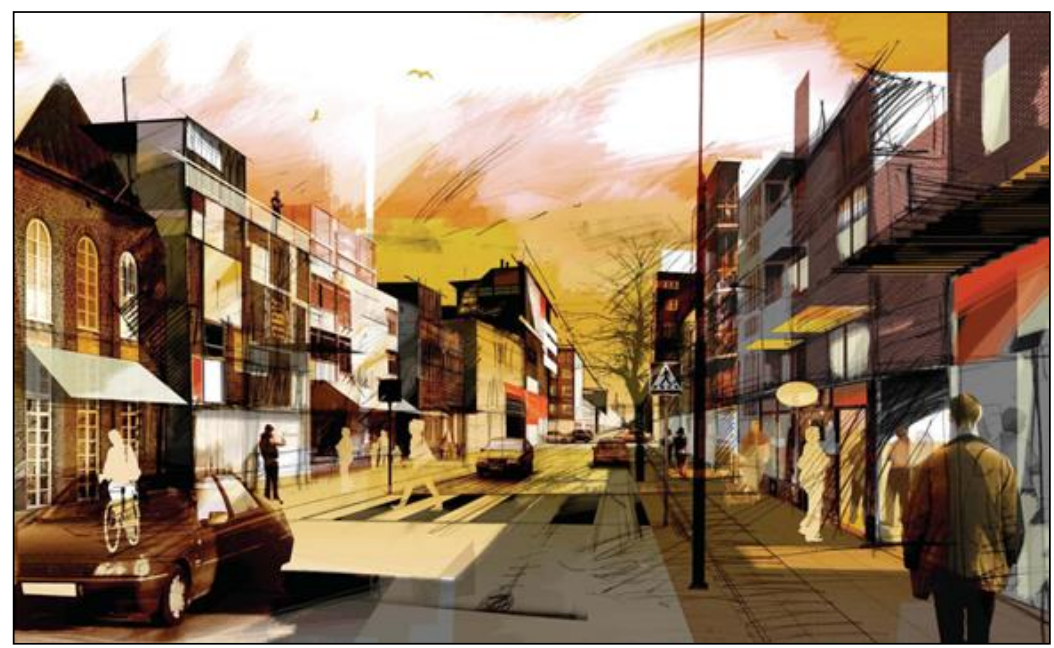


Figure 6- Proposal for a street in Norra Sorgenfri.

Source: Plan program Norra Sorgenfri CMalmö stadsbyggnadskontor

The urban design intervention centres around three auxiliary concepts: Stadsrum (city space), Stadsliv (city life) and Nätverk (network). The endorsement of the Stadsrum concept focuses on developing an area that will attract visitors from within and outside Malmö through the promotion of the main streets as lively areas, with the ambition of strengthening the culture and arts scene that is blossoming already, and through the development of a network of green spaces, cycle paths and pedestrian areas that builds on the wider discourse of Malmö as a sustainable city. The Stadsliv concept is related to the small-scale projects and variation, which are understood as contributing to a lively urban atmosphere. Each small plot can be developed as the stakeholders directly invested in its development reach an agreement. There is no single grand scheme for the final product, other than the abstract idea of what an attractive city centre looks like. Finally the concept of Nätverk is evident in the proposals for the creation of a new network of green spaces and pedestrian and cycle paths, in the promotion of the existing streets as attractive areas to live, shop and invest in, and in the idea of the neighbourhood serving as a connecting area between the centre and eastern parts of Malmö.

\subsubsection{The intangible sphere}

The Stadsrum, Stadsliv and Nätverk concepts are ultimately used to strengthen the image of Malmö as a Knowledge City, with Norra Sorgenfri as an area for artists, local entrepreneurs and cultural industries, and to elaborate on the idea of the redevelopment of a district with creativity and urbanity in its character. Building on the discourses of the tolerant and creative city and how these two aspects can contribute to local economic development (Florida, 2002; 2004; Landry, 2000), the project is meant to bring forth the image of an exciting and tolerant Malmö.

The redevelopment of the district is guided by intentions to build an extension of the city centre and is marked by the goal of marketing Malmö as an attractive place to live and invest in, especially for current inhabitants, and addressing the problem of segregation in Malmö. The function of the district is defined as a place for integration, understood as physical - it serves as the connection between the eastern and central parts of Malmö and the extension of the city centre towards the east - and social, as a new meeting place for the city's inhabitants (Malmö Stad, 2007).

Recently Norra Sorgenfri hosted the first exhibition for and by young people discussing solutions to address the lack of affordable housing in Sweden (UngBo12). Additionally a "Map of Culture" (Kulturkartan) was launched by Malmö Stad highlighting which buildings will house temporary cultural activities in the neighbourhood. The planning team involved in the project is also looking to secure the continued interest and involvement of local politicians and developers in the project, trying to keep them on board with the current vision and aims for the neighbourhood. Developers especially are fearful about the economic profitability of investing in housing and offices in this part of the city (Interview Lundqvist).

4. Place-making by physical planning 
The aim with this paper was to discuss how physical planning works with place-making through urban design to support a municipality that aims to create a new image for the city.

The two projects discussed here represent two different moments in the development of the new image for Malmö. A flagship project - Bo01 - kick-started the process. This project was made possible by the opening of the Öresund Bridge, the locational advantages, the exhibition's theme and the media attention at the time of the exhibition. Flagship developments are used to give one particular and segmented vision of a city, omitting many other conflicting, contrasting and antagonistic images in favour of the single clean, streamlined, consumer-friendly type of heterogeneity advanced by branding strategies. However, for the new image to be secured and strengthened, other less publicised projects have to pick up and reinforce that same image, in what could be seen as the mainstreaming of the city vision through urban development projects. This is the case of Norra Sorgenfri.

When it comes to the intended users for these renovated areas, these projects appear quite distinct, but share striking similarities. Bo01 is a place-marketing tool, with a municipally acknowledged intention of attracting external investments and specific socio economic groups as new inhabitants - middle-uppers classes. Bo01 is promoted for hosting companies in advanced services, consultancy, marketing and media activities, and now hosts a university-college.

Norra Sorgenfri is aimed at civic promotion and the continued rehabilitation of the image of the city for current inhabitants. It can also be seen as a case of reflexive learning, a reaction to the criticisms of Bo01, which was accused of being an enclave for the better-off minority, of not responding to the pressing needs of the city for new housing, and of trying to attract new inhabitants without concern for existing inhabitants and the socio-spatial segregation in the city. It is marketed as an urban and multi-cultural neighbourhood, where students, artists, young people and immigrants can meet each other on the refurbished, clean, safe and attractive streets. It is meant for small-scale retail, ethnic entrepreneurship, and artists' studios, ateliers and designer shops (Malmö Stad, 2007).

In this sense, both images work with a type of inhabitants that Florida (2002) described as the life blood of a city that wants to use "creativity" to promote local economic development, and for the activities credited for the regeneration of local economic growth in the city (Glaeser et al., 2000; Bayliss, 2007; Hutton, 2004).

One could also question which dilemmas are posed to physical planning practice in the context of LSUDPs that promote a built environment for knowledge-based activities and "creative classes". The city image formatted according to an ideal of user and uses loses its heterogeneity, its edge, and the elements of risk, surprise, danger and excitement that derive from nonconformity to suburban middle-class values and norms and from aestheticised environments. Lovering and Sartorio framed this as a new trend in which "those most directly engaged in building the new world (architects, property developers and the planning authorities regulating their effects) have tended to focus increasingly on the generic, extinguishing difference except at a relatively trivial cosmetic level. The notion of a local or individual culture, or of the specific interests and requirements of particular groups, have been thinned out, often meaning little more than a small bit of local repackaging" for off-the-shelf branded orthodoxies" (2007, p.306) 
Norra Sorgenfri is not overtly targeted at specific users, but can gentrification be avoided in this prettified old industrial area? There is the expectation for a type of "trickle-down" effect, with the affluence of the city centre spilling over to Norra Sorgenfri and the east. But this trickle-down effect can have two faces: 1) affluent people move to and around Norra Sorgenfri, attracted by the inviting built environment and the amenities promoted in the area, and squeeze out the lowincome households in the surrounding areas and eastwards; or 2) the urban development does create new jobs in the area, some of which employ people from the eastern districts, and attracts people from all over Malmö to come to the district for shopping, work and/or leisure. Given that the urban development project thus far has had concrete ideas about how to promote the built environment but has been less forthcoming in how promote local entrepreneurship and the creation of new jobs in the area, this author suspects that the first consequence is more plausible (Interviews Thesselius, and Rosell and Norgren).

Some physical planning approaches have changed from the 1970s, namely the promotion of mixed-use areas, pedestrian friendly environments, and the abstractly defined "diversity" that is expected to emerge in built forms, usages and users of these districts. But one cannot help but noticing the large-scale dimension of these projects and the equally daunting ambitions for the socio-economic revitalisation of the city that are associated with it. As the Million Homes Programme developed large districts for the working classes of industrialising Sweden, so do these LSUDPs of the Entrepreneurial City (Hall and Hubbard, 1998; Swyngedouw et al., 2002) develop "the urban" for a new class of potential workers and mobilisers of the economic activities of the 21 st century - a large-scale transformation and re-fitting of the city to face intercity competition.

This paper thus highlights how the place-making by physical planning thus reflects the entrepreneurial style adopted by the municipality in its quest to draw the media's attention to the city and attract investors. Several dilemmas derive from this role for physical planning practice, namely the mainstreaming of values and urban forms that are oriented towards segmented parts of the population and to specific economic activities, or in the reproduction of urban forms that embody just what can be commodified to promote a specific vision or image of the city, associated with the generic "landscapes of the post-industrial city". The question remains what might be lost for the city itself, and for physical planning in particular, in this drive to achieve the Knowledge City in images and urban forms.

\section{List of interviewees}

P. Andersson - project manager, Real Estates Department, Malmö. 18.05.2011

G. Blucher - former head of Bo01AB. 22.02.2011 and 20.09.2011

B. Johansson- Planner, Planning Department, Malmö. 07.032011

G. Kronwall and U. Lundqvist - former and current project managers for Norra Sorgenfri project, Malmö. 30.03.2011

C. Larsson - Head of Planning Department, Malmö. 27.02.2012 
U. Lundqvist - current project manager for Norra Sorgenfri, Malmö. 12.10.2012

I. Reepalu - Mayor of Malmö and member of board of Bo01AB. 20.03.2012

G. Rosberg- Information Officer, Malmö. 03.03.2011

A. Rosell and H. Norgren- MKB. 15.01.2013

P. Theselius - architect, Streets and Parks department, Malmö. 10.12.2012

\section{References}

Amin, A. \& Thrift, N. (1995) Globalisation, institutional "thickness" and the local economy. (In P. Healey, S. Cameron, S. Davoudi, S. Graham, \& A. Madanipour (1995) Managing Cities: the New Urban Context, Chichester: John Wiley \& Sons).

Appelbaum, R. P. (1985) Swedish Housing in the Postwar Period. Urban Affairs Review, 21(2), 221-244

Ashworth, G. \& Kavaratzis, M. (2007) Beyond the logo: Brand management for cities. Journal of Brand Management, 16, 520-531.

Barnes, K., Waitt, G., Gill, N. \& Gibson, C. (2006) Community and nostalgia in urban revitalisation: a critique of urban village and creative class strategies as remedies for social 'problems'. Australian Geographer, 37(3), 335-354.

Bayliss, D. (2007) The Rise of the Creative City: Culture and Creativity in Copenhagen. European Planning Studies, 15, 889-903.

Ben-Joseph, E. (2009) Commentary: Designing Codes: Trends in Cities, Planning and Development. Urban Studies, 46(12), 2691-2702.

Bianchini, F., Dawson, J. \& Evans, R. (1992) Flagship Projects in Urban Regeneration. (In P. Healey, S. Davoudi, M. O’Toole, S. Tavsanoglu, \& D. Usher (Eds.) Rebuilding the city: Property-led urban regeneration, (London: E\&FN Spon), 245-255.

Blucher, G. (2006) 1900-talet - det kommunala planmonopolets århundrade (In G. Blucher \& G. Graninger (Eds.) (2006) Planering med nya förutsättningar. Ny lagstiftning, nya värderingar, Linköping: Linköping University Electronic Press), 133-156

Bradley, A., Hall, T. \& Harrison, M. (2002) Selling Cities: Promoting New Images for Meetings Tourism. Cities, 19(1), 61-70.

Carmona, M., Magalhães, C. D. \& Edwards, M. (2002) What value urban design? Urban Design International, 7, 63-81.

Dannestam, T. (2009) Stadspolitik i Malmö. Dissertation (Lund: Lund University).

Florida, R. (2002) The Rise of the Creative Class, (New York: Basic Books). 
Florida, R. (2004) Cities and the Creative Class, (London: Routledge).

Glaeser, E., Kolko, J. \& Saiz, A. 2001. Consumer city. Journal of economic geography, 1(1), 27-50.

Gold, J. R. \& Ward, S. V. (1994) Place Promotion: The Use of Publicity and Marketing to sell Towns and Regions. (Chichester: John Wiley).

Gospodini, A. (2006) Portraying, classifying and understanding the emerging landscapes in the post-industrial city. Cities, 23(5), 311-330.

Hall, T. \& Hubbard, P. (Eds.) (1998) The entrepreneurial city: geographies of politics, regime and representation, (Chichester: Wiley).

Hamnett, C. \& Whitelegg, D. (2007) Loft conversion and gentrification in London: from industrial to postindustrial land use. Environment and Planning A, 39, 106-124.

Harvey, D. (1989) From managerialism to entrepreneurialism: The transformation in urban governance in late capitalism. Geografiska Annaler, 71(1), 3-17

Harvey, D. (2006) The Political Economy of Public Space (In S. Low \& N. Smith (Eds.) The politics of public space. (New York: Routledge).

Hedin, K., Clark, E., Lundholm, E. \& Malmberg, G. (2012) Neoliberalization of housing in Sweden: Gentrification, filtering, and social polarization. Annals of the Association of American Geographers, 102(2), 443-463.

Holgersen S. (2012) Exploring urban development in Malmö City through discourses on change. In K. Jacobsson \& K. Sjöberg (Eds.) Pondering on methods. A variety of methodological concerns. (Lund: Lund University).

Hospers, G.-J. \& Pen, C.-J. (2008). A View on Creative Cities Beyond the Hype. Creativity and Innovation Management, 17(4), 259-270.

Hubbard, P. (1995) Urban design and local economic development: A case study in Birmingham. Cities. 12(4), 243-251.

Hubbard, P. (1996) Urban Design and City Regeneration: Social Representations of Entrepreneurial Landscapes. Urban Studies, 33(8), 1441-1461.

Hutton, T. A. (2004) The New Economy of the inner city. Cities, 21(2), 89-108.

Hutton, T. A. (2006) Spatiality, built form, and creative industry development in the inner city. Environment and Planning A, 38(10), 1819-1841.

Jensen-Butler, C., Shachar, A. \& van Weesep, J. (eds.) (1997) European Cities in Competition. (Aldershot: Avebury).

Landry, C. (2000) The Creative City: A Toolkit for Urban Innovators (London: Earthscan).

Lovering, J. \& Sartorio. F. (2007) Editorial, International Planning Studies, 12(4), 305-307 
Macleod G. \& Johnstone, C. (2012) Stretching Urban Renaissance: Privatizing Space, Civilizing Place, Summoning 'Community'. International Journal of Urban and Regional Research, 36(1), 1-28.

Madanipour, A. (2006) Roles and Challenges of Urban Design. Journal of Urban Design. 11(2), 173193.

McGuirk, P. M. \& MacLaran, A. (2001). Changing Approaches to Urban Planning in an 'Entrepreneurial City': The Case of Dublin. European Planning Studies, 9(4), 437-457.

Malmö Stad (2005) Aktualisering och komplettering av Malmös översiktsplan. (Malmö: Stadsbyggnadskontor).

Malmö Stad (2007) Vision Norra Sorgenfri. (Malmö: Stadsbyggnadskontor). Retrieved on 2010/03/05 from: http://www.malmo.se/download/18.1c002f7b12a6486c372800012149/vison-norra-sorgenfrieng.pdf

Malmö Stad (2008a) Områdesfakta. (Malmö: Avdelning för Strategisk Utvekling). Retrieved on 2013/02/05 from: http://www.malmo.se/Kommun--politik/Om-oss/Statistik/Omradesfaktafor-Malmo/Omradesfakta-2008-rev.-areal--och-biluppgifter.html

Malmö Stad (2008b) Planprogram Norra Sorgenfri. (Malmö: Stadsbyggnadskontor). Retrieved on 2010/03/05 from: http://malmo.se/Medborgare/Stadsplanering--trafik/Stadsplanering-visioner/Utbyggnadsomraden/Norra-Sorgenfri/pagefiles/Norra-Sorgenfri-

planprogram_reviderat_skarm.pdf

Malmö Stad (2012) Västra Hamnen i siffror. (Malmö: Stadsbyggnadskontor). Retrieved on $15 / 09 / 2012$ from: http://malmo.se/download/18.1558e15e13973eeaa0e800018904/v\%C3\%A4stra+hamnen+i+sif fror $+2012+$ september.pdf

Malmö Stad (2013) Översiktsplan för Malmö ÖP2012. Planstrategi. Utstälningsförslag. (Malmö: Stadsbyggnadskontor) Retrieved 2013/01/31 from: http://malmo.se/download/18.723670df13bb7e8db1bc547/OP2012_planstrategi_utstallningsfo rslag_web_jan2013.pdf

Marcuse, P. (2005) 'The city’ as perverse metaphor. City, 9, 247-254.

Mukhtar-Landgren, D. (2005) Den delade staden- Välfärd för alla i kunskapsstaden Malmö. Fronesis, 18, 120-131.

Mukhtar-Landgren, D. (2008) Utopi ich dystopi i postindustriella Malmö. In Jensen, E. L. \& Ouis, P. (Eds.) Inne och Ute i Malmö. Studier av urbana förändringsprocesser. (Malmö: Malmö Högskola).

Möllerström, V. (2011) Malmös omvandling. Från arbetstad till kunskapsstad, Dissertation (Lund: Lund University).

OECD (2007) Competitive Cities. A new entrepreneurial paradigm in spatial development. (Paris: OECD Publishing). 
Paddison, R. (1993) City Marketing, Image Reconstruction and Urban Regeneration. Urban Studies, 30(2), 339-349.

Peck, J. (2005) Struggling with the Creative Class. International Journal of Urban and Regional Research, 29(4), 740-770.

Planering i Malmö (2010:2) Informations från Malmö Stadsbyggnadskontor. (Malmö: Malmö Stad)

Rousseau, M. (2009) Re-imaging the City Centre for the Middle Classes: Regeneration, Gentrification and Symbolic Policies in 'Loser Cities'. International Journal of Urban and Regional Research, 33(3), 770-788.

Russo, J. (2008). Regeneration and Tourism Development. Evidence from Three European Cities. Working paper series (Venice: Department of Economics of the Ca' Foscari University of Venice).

Schlyter, O. (2006) Norra Sorgenfri - kulturbistorisket underlag inför planprogram. Byggnadsantikvarisk utredning. Malmö Stad, Enheten för Kulturmiljövård Rapport 2006:026.

Shimomura, T. \& Matsumoto, T. (2010) Policies to Enhance the Physical Urban Environment for Competitiveness: A New Partnership between Public and Private Sectors. (Paris: OECD Publishing).

Smith, N. (2002) New globalism, new urbanism: gentrification as global urban strategy. (In N. Brenner and N. Theodore (Eds.), Spaces of neoliberalism, Blackwell, Oxford).

Stigendal, M. (2004) Transformations, Boundaries, Dialogues (paper presented at the 22nd Nordic Sociology Congress, Malmö)

Strömgren, A. (2007) Samordning, hyfs och reda: Stabilitet och förändring i svensk planpolitik 1945-2005. Dissertation (Uppsala: Uppsala University).

Tasan-Kok, T. \& Baeten, G. (eds.) 2012. Contradictions of Neoliberal Planning. Cities, Policies, and Politics (Dordrecht: Springer).

Swyngedouw, E., F. Moulaert, et al. (2002). New Geographies of Power, Exclusion and Injustice Neoliberal Urbanization in Europe: Large-Scale Urban Development Projects and the New Urban Policy. Antipode 34(3): 542-577

Vall, N. (2007) Cities in Decline? A Comparative History of Malmö and Newcastle After 1945 (Malmö: Malmö Högskola).

Wood, A. (1998) Making sense of urban entrepreneurialism. Scottish Geographical Magazine, 114(2), 120-123.

Yin, R. K. (2003) Case study research: design and methods (Thousand Oaks: Sage Publications).

Zukin, S. (1995) The Cultures of Cities (Oxford: Blackwell Publishers). 